УДК 316.334.(477.87)

DOI https://doi.org/10.32840/2707-9147.2020.85.9

H. I. ВАРГА

\title{
ПЕРСПЕКТИВИ КОНЦЕПТУАЛЬНОГО ДОСЛІДЖЕННЯ НЕФОРМАЛЬНОЇ ЗАЙНЯТОСТІ
}

У статті розглянуто концептуальні перспективи дослідження неформальної зайнятості. Дуальний характер інституційного середовища набуває вираженої специфіки в умовах інституційних змін у перехідних суспільствах. Формується феномен подвійної інституціоналізації як специфічної ознаки перехідного суспільства. У процесі зростання альтернативних інститутів порушується певний інституційний баланс як між офічійними інститутами, так і між неформальними інститутами, а також між новими офіційними і старими неформальними інститутами.

Мета статті - надати критичний огляд того, як було визначено та виміряно зайнятість у сфері неформальної інформачиї, разом із відібраними висновками щуодо ї̈ ступеня та характеру, а також короткий огляд конкуруючих поглядів щзодо ї̈ ролі в сучасній економіці та як з нею можна боротися. У статті описано процес інституціоналізації неформальних практик, щуо пронизують кожну окрему форму економічної реальності - це компроміс формальних правил та сочіальних норм. Тобто неформальні практики кореняться в розриві законів та неписаних норм поведінки. Показано глибокий розрив а також слабкий механізм правозастосування для дотримання закону, частіше зустрічаються неформальні практики. Так само неформальні практики не просто закорінені в законах $і$ соціальних нормах, а, будучи масовими, неминуче призводять до "руйнування опор», а саме спонукання до свідомої корекциї законів та ненавмисної модифікації сочіальних норм суспільства. Самі формальні правила застосовуються виключно під впливом неформальної практики. Вони нерозлучні. Тимчасова, змінна або епізодична зайнятість (зайнятість на основі строкових контрактів на основі договорів на певний обсяг роботи, сезонна зайнятість тощо) набула широкого поширення в нашій країні в умовах перехідної економіки як стратегія адаптації до мінливих умов. Здійснено порівняльний аналіз nідходів, щуо обговорюються. Обтрунтовано необхідність вивчення неформальної зайнятості, розуміння цьього явища та необхідність його регулювання.

Ми дійшли висновку, щзо формальне та неофіційне існують окремо, використовуючи при иььму термін «сектор». Але як тільки ми вступаємо в дискусію про бюрократичне та небюрократичне управління, ми помічаємо безперервність формальних та неофічійних замовлень. У даній статті загальний вектор досліджень неформальної економіки змімується від структурного до інституиійного. Обов'язково слід використовувати комплексний підхід, який включає положення та теоретичні елементи різних шкіл. Так, неформальна та формальна економіка держави переплітаються та утворюють певний соціальний контекст функиіонування неформальної зайнятості. Доведено, щуо співвідношення формального та неформального регулювання має не менше

(C) Варга H. I., 2020 
трьох класів. Неформальні практики можуть: витісняти формальні правила, замінюючи їх; займати простір, вільний від формального регулювання; порушувати «не букву, а дух закону», використовуючи юридичний інструмент як інструмент для досягнення неформальних домовленостей.

Неформальна, вторинна зайнятість дозволяє певною мірою забезпечити мобільність та більш високий рівень зайнятості в иьому випадку, зменшуючи ризик безробіття та збільшуючи шанси на зайнятість. Це безумовно відповідає інтересам прачівників, дає можливість недоїдання, шанс отримати свої периі гроші та відчути себе незалежними. Не слід забувати, щзо працівник передусім вважає нестандартну зайнятість відсутністю соиіального захисту. До об'єктивних недоліків неформальної зайнятості прачівників відносяться низький рівень оплати праці, відсутність контролю за безпекою робочих місиь і в більшості випадків - відсутність кар'єрних перспектив.

Ключові слова: зайнятість, неформальна зайнятість, сочіальна довіра, експолярна економіка.

У сучасних умовах окремий інтерес до проблеми неформальної зайнятості з'являється у зв'язку із швидким поширенням різних нових форм зайнятості, які не вписуються у сформовані уявлення про формальну, стандартну зайнятість. Таким чином, можна стверджувати, що об’єкт дослідження розвивається і ускладнюється. Неформальна зайнятість, яка спочатку визначалась як характеристика відсталості країни «третього світу», почала сприйматись як певна модель господарювання, що має свою специфіку в кожній із країн.

Різноманітність і поширеність неформальних соціальних інститутів створює серйозні перепони на шляху їх офіційної інституціоналізації. Через це актуальною стає їх диференціація на універсальні та локальні, позитивні, нейтральні і деструктивні форми неформальних регуляторів. Таке розмежування дозволить ідентифікувати неформальні соціальні практики на ті, які потребують інституціоналізації у формі якісного оновлення інституційної системи української держави і суспільства; і ті, які цьому перешкоджають.

Передумови дослідження неформальної зайнятості на ринку праці містяться у працях Д. Гершуні, М. Гранноветера, Хоманса, Блау, Г. Гросмана, П. Гутманна, М. Кастельса, Ф. Матера, Э. Мінгионі, Д. Норт, К. Поланьї, А. Портеса, Р. Роуза, Э. де Сото, Д. Старка, В. Танзи, Дж. Томас, В.Э. Файге, К. Харта, Уільямса С. У країнах пострадянського простору концептуальні основи неформальної зайнятості закладені у працях С.Ю. Барсукової, Т.И. Заславскої, Ю.В. Латова, В.В. Радаєва, Н.Н. Сєдовой, Т. Шаніна. Щодо вітчизняних науковців, то варто відміити Т. Петрушину, Е. Лібанову, А. Позняка, О. Малиновську (проблеми трудової міграції), Л. Хижняк, Ю. Пачковського, С. Пилипенко, М. Туленкова, М. Лукашевича, С. Сірого.

Метою статті $\epsilon$ дослідження сутності концепту «неформальна зайнятість» у транзитивному суспільстві.

Здатність інституціональної структури до саморегулювання створює своєрідний «ефект блокування», визначається залежністю 
організації від інституційних рамок, в яких вони виникли. I формальні, i неформальні інституційні обмеження приводять до формування суспільних утворень, які структурують взаємодію в суспільстві.

3 огляду на різнорідність неформальної економіки доречно розглядати аспекти функціонування неформальної зайнятості комплексно. Економічні відносини та інститути є невід'ємною частиною політичних, соціальних і культурних контекстів, у межах яких вони функціонують, де неформальна зайнятість зображується як форма суспільного життя. Характер неформальної економіки відрізняється в залежності від соціально-економічної, політичної структури країни. Ураховуючи контекстуальне середовище впливу на функціонування неформальної економіки, варто уявити цілісну і складну соціальну картину.

Обмеженнями ряду наукових підходів є саме неврахування соціальних і політичних передумов у функціонуванні неформальної зайнятості. Адже дослідження неформальної зайнятості варто реалізовувати в певному соціально-політичному і культурному контексті, що дозволяє більш цілісно і комплексно враховувати ії складний і гетерогенний характер. Неформальна економіка характеризується цілим комплексом функціональних чинників, а саме: економічних, соціальних, інституційних, екологічних впливів, включаючи безробіття і рівень достатку, соціальні мережі, локальну культуру і форми регулюючого впливу. Контекст певного соціального часу і простору визначає характер неформальної зайнятості, іiї масштаби, фактори розвитку, цілі роботодавців і працівників.

Нагальним $\epsilon$ використання комплексного підходу, що включатиме положення і теоретичні елементи різних шкіл. Так, неформальна і формальна економіки держави переплітаються і формують певний соціальний контекст функціонування неформальної зайнятості. Проілюструвати це можна на прикладі вуличних торговців, які часто працюють неофіційно через свій правовий статус. Неформально зайняті у промисловій діяльності працівники не можуть впливати на своїх роботодавців (отримувати соціальний захист, впливати на кадрову політику), особливо в глобалізованому світі, коли підприємства і робітники знаходяться на різних континентах. Водночас самозайняті реалізовують свою діяльність в домогосподарствах, мають обмежений ринок реалізації, укладання угод, низький рівень і відсутність можливості отримувати кредити [84].

Різні концепції і уявлення про неформальну зайнятість можуть бути адаптовані залежно від типу неформальності і сфери дослідження. Отримує своє підтвердження теза про те, що неформальна зайнятість може розглядатись, як пережиток традиційної економіки, яка відповідає теорії дуалістичної школи; неформальна зайнятість може виступати в ролі побічного продукту функціонування офіційної економіки, що відображено в структуралістській школі; неформальна зайнятість як альтернатива формальній зайнятості, яка розглядається в рамках 
легалістського підходу і неформальна зайнятість - в якості доповнення до офіційної зайнятості, яку варто розглядати як комплексний феномен.

Уільямс стверджує, що існує широкий спектр неформальних видів діяльності, для кожного з яких варто підібрати певне теоретичне пояснення [2]. Наприклад, широкий спектр неформальної самозайнятості населення знаходить своє пояснення в рамках позитивної альтернативи до формальної зайнятості у формі самозабезпечення. 3 іншого боку, уявлення про іiі функціонування може розширюватись, коли мова йде про безоплатну роботу і підтримку друзів, родичів, сусідів у формі незаявленої «економіки дарунку» і підстраховки у важкій життєвій ситуації. Таким чином, досить важко робити універсальні узагальнення щодо неформальної зайнятості, надалі визначаючи актуальність комплексного підходу у іï функціонуванні.

У логічній системі сучасної економічної теорії пріоритетною стає концепція двосторонньої економіки. Дихотомія «сучасне-традиційне», «промислове-аграрне», «ринкове-неринкове» $\epsilon$ результатом внутрішньої логіки розвитку економічної науки. Дослідники єдині в тому, що економіка країн, що розвиваються, і перехідна економіка можуть моделюватися як двосекторальні структури. Дуалізм, який закладений в основі поведінки економічного суб'єкта, є визначальним. Ця поведінка не завжди раціональна з точки зору формальних інститутів суспільства. Так, оптимізуючи прибутки і витрати, нехтуючи сплатою податків, економічний агент може чинити нераціонально по відношенню до формальних інститутів держави. Індивід буде прагнути до максимально можливого зменшення прибутку, який піддаватиметься оподаткуванню, навіть ціною функціонування в неформальному секторі економіки. Неформальна діяльність виникає там, де очікування прибутковості перевищує очікування витрат. Поділ економіки на формальний і неформальний сектори в методологічному плані привертає увагу збереженням дуальної моделі [3].

Концептуальною складовою частиною неформальної зайнятості виступає саме соціальний капітал. Для посткомуністичних країн досить влучно підходить визначення Бурдьє: «Соціальний капітал являє собою сукупність фактичних або потенційних ресурсів, які пов'язані з належністю до певної соціальної мережі, певних інституціоналізованих відносин взаємного знайомства і визнання». Бурдьє відзначає символічні переваги функціонування соціального капіталу. Проте, очевидно, перспектива лежить е людині, а не в інтеракціях або колективних уявленнях. У цьому сенсі соціальний капітал є явищем мікрорівневого характеру, що належить фізичній особі і відображає неформальні соціальні мережі. Варто більше уваги приділяти таким соціальним явищам, як довіра і громадська участь, а також роль, яку вони відіграють у розвитку, що може поліпшити ефективність суспільства шляхом сприяння узгодженим діям [4]. 
Неформальний сектор економіки являе собою інституційне поле неформальних інститутів. Неформальна зайнятість - один із багатьох інститутів, що формують це поле. Інститути неформального сектора можна представити як «скрізні». Варто розглядати зайнятість у неформальному секторі економіки як сукупність прихованої, неформальної економічної діяльності.

Важливою особливістю історії сучасної економіки пострадянських країн виступає також господарський традиціоналізм. Традиційна економіка протирічить інноваційному типу економіки, що характерна для західного світу, і спирається на сформовані звичаї, традиції у сфері форм організації господарської діяльності.

Подібні погляди відстоює i субстантивістська соціологія. Підкреслюючи вплив інституційної системи на характер розвитку суспільства, цей науковий напрям допускає складний і неоднозначний зв'язок між інститутами і практикою економічного життя. Невипадково ідеї К. Поланьї тісно пов'язані із класичною антропологією. Вивчаючи розвиток соціальних інститутів, антропологи (Б. Малиновський, Р. Турнвальд) довели, що норми поведінки у традиційних суспільствах часто не співпадають із раціональними схемами, які характерні для західного світу. Ринково орієнтованому європейцю важко зрозуміти соціальний порядок традиційних суспільств [5]. Між тим нераціональність інститутів «дикарів» опиняється раціональністю іншого типу, зорієнтованою на спільне виживання громадою. Дослідження антропологів показують можливість (і стійкість) суспільств, в яких соціальні норми не виростають із економічного егоїзму індивіда, а стримують його. Саме ці ідеї К. Поланьї розвиває у своїй праці «Велика трансформація», де аналізується історія становлень ринкових відносин у західних суспільствах [5]. Ринкові відносини зародились і розвивались за безпосередньої підтримки держави. Саме це стимулювало утворення національних ринків у період формування держави. Без прямої участі держави ринкові відносини не могли об'єднатись у форми, протилежні ліберальним поглядам на державу як антитезу ринку. По-друге, домінування ринкової логіки над соціальними нормами з'явилось порівняно недавно. У докапіталістичну епоху ринкові відносини були «вбудовані» в соціальний каркас дозволеності. «Хоча сам інститут ринку був досить поширеним починаючи з пізнього кам'яного віку, проте його функція в економічному житті залишалась досить другорядною» [87, с. 55]. I лише у XXI ст. соціальні норми почали витіснятися економічною доцільністю, а соціальний статус людини залежати від іiі капіталу. Поглинання соціального життя економічним порядком відбувається в міру «комодифікації» суспільства (от англ. commodity - товар) процесу, що втягує в товарообіг нові явища і відносини.

«Безшкодний інститут ринку роздався соціальним вибухом... Якщо раніше економічна система була вкорінена в соціальних відносинах, 
то тепер соціальні відносини опинились укоріненими в економічній системі» [5, с. 510].

Ідеї К. Поланьї отримали продовження і розвиток в інституційній соціології, яка трактує інститути як свого роду правила гри. Саме вони не тільки фіксують стійкі правила господарського життя, але і конструюють це життя, надаючи йому форми, які не виробляються стихійною практикою. Проте інша справа, що ці інститути ефективні лише тією мірою, якою спираються на традиції, а їх реформування проходить «рішучими, але повільними кроками».

Урахування традицій і культурного підгрунття в економічній діяльності співвідносить інституційну соціологію 3 німецькою історичною школою. 3 точки зору консерватизму провина «тіньовиків» не в тому, що вони наносять шкоду державному бюджету, а в тому, що вони руйнують правила гри, на яких тримається суспільство.

Природа соціальних та економічних інститутів не залежить від волі людини. Сили прогресу і розвитку формують інституційний каркас i задають правила. Якщо дані норми ігноруються масами, значить, вони неадекватні історичному виклику [5].

Так, розхитування старого інституційного каркасу і поява зразків поведінки, що не вписуються в рамки дозволеного, передує змінам. Будь-яка організаційно-господарська інновація виникає «в тіні» і тільки в міру дозрівання історичних умов отримує шанс на інституціоналізацію.

Звідси випливає неоднозначне ставлення до сфери неформальної економіки і зайнятості: вони оцінюються як явище прогресивне або, навпаки, регресивне в залежності від історичного контексту. У періоди, коли формальні інститути стримували рух суспільства вперед, неформальна економіка може вважатись прогресивною (самозайнятість населення в радянський час). Коли ж суспільство функціонує в рамках формальної ринкової економіки, задіяність населення в неформальній зайнятості розглядається як традиціоналізм і регрес.

Концептуально проблема неформальної зайнятості може бути розглянута в категоріях «дуальної економіки» - формальної та неформальної. Спеціаліст у рамках економічної антропології, К. Гірц у рамках економічної системи країн, що розвиваються, виділяє дві підсистеми - «базарну» та «зорієнтовану на фірмове виробництво» економіки. Ці дві системи можна протиставити з точки зору ефективності функціонування [5].

Так, наприклад, Т. Шанін пропонує оригінальну концепцію так званої «експолярної економіки», сутнісні характеристики якої «не відповідають ні одному з концептуальних полюсів». Основні сутнісні ознаки цієї економіки - соціальне «укорінення» цього явища, «відстороненість» від державного та ринкового капіталізму, особливі стратегії виживання, що беруть початок у способах функціонування сімейних економік. Таким чином, «експолярна економіка» як система 
протистоїть як ліберальному ринку, так і державній плановій економіці, має власну соціокультурну логіку функціонування. Можливо, саме завдяки цій економіці пострадянське суспільство змогло вижити і пристосуватись до змінних ринкових трансформацій [5].

Переважна більшість дослідників розглядає неформальну економіку в країнах, що розвиваються, як можливість збільшення маргінальної зайнятості для міських малозабезпечених прошарків населення та жінок: як первинну мережу забезпечення соціальної безпеки, набуття професійних навиків і регулярної підтримки підприємців, які задіяні в неформальній економіці, які могли б переміститися в легальний сектор і подолати проблему безробіття і бідності в цих країнах.

Більшість теоретиків вважають, що неформальна зайнятість може бути зрозумілою лише за умови врахування іiі маргінального положення у складі інтегрованої економіки. Як відзначалось, задіяність у неформальній зайнятості в більшості випадків реалізовується в основному людьми 3 низьким соціально-економічним статусом, для яких вона виступає своєрідним захистом від бідності [6]. Прихильники цього погляду відзначають, що наявність низки бар’єрів в офіційному секторі працевлаштування, особливо для жінок, призводить до їх задіяності в неформальному секторі, гарантуючи тим самим елементарне виживання. Інші науковці вважають, що формальна і неформальна зайнятість виступають взаємозамінними по відношенню одна до одної: коли люди втрачають роботу в офіційному секторі, то вони можуть переміщатись у неформальний [6].

Неформальна економіка частково виникла як реакція на сімейні або суспільні потреби, а не як прагнення до отримання економічної вигоди. Неформальні обміни є більш поширеними в сільських домогосподарствах, де вони виступають стратегією виживання для значної кількості населення. Ці мережі виступають джерелом потенційної економічної підтримки у важких ситуаціях і більш пристосовані до існування в групах із сильними соціальними мережами.

Важливими факторами, що впливають на функціонування неформальної економіки, є норми довіри і солідарності. Особлива увага при цьому приділяється розгляду проблеми співвідношення міжособистісної та інституційної довіри. Передбачається, що чим вищий рівень міжособистісної і інституційної довіри, тим вищий рівень соціального капіталу в суспільстві, тим менше виникає передумов для неформальних господарських практик і навпаки.

Проведені дослідження показують, що високий рівень міжособистісної довіри досить тісно корелює з поширенням неформальної солідарності і практик взаємодопомоги. Крім того, низький рівень інституційної довіри протилежно впливає на прояв таких соціальних норм, як «чесність» і «повага до закону» [8].

Схожі результати про низький рівень позитивних установок по відношенню норм права і відповідних позаправових практик представлені 
в дослідженні Т. Заславської і М. Шабанової [9, с. 165]. Аналізуючи процес соціально-економічної трансформації в період 1990-х років, деякі дослідники зробили висновок, що в результаті «склалася ситуація безперечного переважання неформальних відносин над формальними, руйнування старих формальних регуляторів відкрило широкі можливості для їх заповнення неформальними відносинами. Неформальні відносини не $є$ відносинами з ринковими властивостями - вони несуть на собі соціокультурний відбиток попереднього розвитку».

Таким чином, приходимо до висновку, що представлена перспектива вивчення функціонування неформальної економіки і зайнятості розглядається в контексті впливу соціокультурних норм суспільства i їх відтворення, впливу на структуру соціального капіталу.

Варто враховувати той факт, що в Україні функціонують схеми економік неринкового типу. Важливим фактором, що впливає на осмислення неринкової парадигми, стало розуміння того, що ринкові реформи, не дивлячись на волю політичних лідерів країни і активний вплив міжнародних сил, наштовхуються на «становий хребет», інші економічні відносини, які по-своєму переосмислюють хід трансформаційних процесів.

Підсумовуючи, відзначимо, що базові інститути формуються на основі історичного досвіду в результаті пристосування населення, що проживає на території держави, до наявних умов. У процесі розвитку суспільства базові інститути проявляються в більш розвинутих формах, зберігаючи при цьому якісну специфіку. Базові інститути взаємозумовлені, визначають зміст і підтримують функціонування один одного, тобто формують певну систему. Головною функцією базових інститутів виступає підтримка цілісності суспільства у формі єдності всіх підсистем, що регулюють важливі сфери суспільного життя.

У даному контексті економіка і неформальна зайнятість, зокрема, можуть розглядатися як із матеріальної, так і з інституційної точок зору. У першому випадку економіка як «господарство» $\epsilon$ сферою, в якій суспільство приймає і реалізує рішення про використання обмежених, дефіцитних ресурсів для задоволення базових потреб, сфера, де виробляються і споживаються життєві блага. За такого розуміння «економічний» означає «такий, що має відношення до задоволення матеріальних потреб» [6].

3 іншого боку, в процесі господарської діяльності в суспільстві складаються певні економічні інститути. Саме там закріплюється соціальна практика, що визначає способи взаємодії господарських суб'єктів в умовах конкретної матеріально-технологічної сфери. За такого підходу економіка розглядається як система інститутів що формують господарську діяльність [10]. За межами економічного мейнстріма все більш поширеними є уявлення про множинність типів економік, які існують і взаємодіють у часі і просторі.

Соціологічний погляд на тіньові практики значно ширший. Склад інституційної системи в період трансформації такий, де відбувається 
явне домінування неформальних, тіньових відносин та інститутів над офіційними відносинами та інститутами. На думку P.I. Капелюшнікова [11], інституційну природу перехідних суспільств визначає саме цей рух - від формальних «правил гри» до неформальних, від явних контрактів до прихованих. Маємо ситуацію, коли у всіх галузях господарського механізму - на ринку капіталу, на ринку праці, у відносинах між різними гілками і рівнями влади переважають неписані правила і домовленості, що мають перевагу над вимогами закону, умовами контрактів та іншими формальними обмеженнями. Виходячи 3 фундаментального положення, що складно організовані соціальні системи не здатні функціонувати в абсолютному інституційному вакуумі, можна говорити про те, що у всіх постсоціалістичних країнах утворені пустоти почали заповнюватися діями неформальних інститутів, неявних контрактів і тіньових практик.

Тіньові практики, що виникли в радянській економіці, до теперішнього часу поширюються і активно реалізуються в політиці, соціальній сфері і сфері зайнятості зокрема. Закон втратив свою обов'язкову силу, а практика його використання не реалізується. Це означає, що в Україні, як і в усіх трансформаційних суспільствах, період ослаблення інституційних систем не просто затягнувся, а, навпаки, прийняв стійку, стабільну форму, і що наше суспільство опинилось у стані стаціонарної інституційної нерівноваги. Важливо відзначити, що 3 точки зору аналізу неформальності у сфері трудових відносин неформальні правила можуть бути розширенням, продовженням, доповненням формальних правил, оскільки останні визначають вибір альтернатив без урахування обставин тієї чи іншої одиничної угоди. Цей вид відносин між двома типами правил найбільш поширений у суспільних системах, що розвиваються еволюційним шляхом, в яких налагоджений процес відбору найбільш життєздатних норм поведінки. Останні виникають спонтанно із щоденної взаємодії між контрагентами.

\section{Список використаної літератури}

1. Chen M., Jhabvala R., Lund, F. Supporting Workers in the Informal Economy: a policy framework. Working Paper on the Informal Economy. Geneva : International Labour Office, Employment Section. 2002. 53 p.

2. Williams C.C., Round, J. Re-thinking the Nature of the Informal Economy: Some Lessons from Ukraine. International Journal of Urban and Regional Research. 2007. Vol. 31.2. P. 425-441.

3. Барсукова С. Ю. Неформальная экономика: причины развития в зеркале мирового опыта. Проблемы прогнозирования. 2000. № 4. С. 152-158.

4. Бурдье П. Социология социального пространства / Общ. ред. Н.А. Шматко. СПб. : Алетейя; М. : Ин-т эксперим. социологии: Алетейя, 2005. 288 с.

5. Шанин Т. Эксполярные структуры и неформальная экономика современной России. Неформальная экономика: Россия и мир. / Под ред. Т. Шанина. М. : Логос. 1996. $576 \mathrm{c}$.

6. «Великая трансформация» Карла Поланьи: прошлое, настоящее, будущее / Под общей ред. Р.М. Нуреева. (Серия «Конференции Департамента экономической теории ГУ-ВШЭ»). М. : ГУ-ВШЭ, 2007. 321 с. 
7. Заславская Т.И., Шабанова М.А. Социальные механизмы трансформации неправовых практик. Общественные науки и современность. 2001. № 5. С. 5-24.

8. Нуреев Р.М., Ахмадеев Д.Р. Формальная и неформальная занятость как «близнецы-братья»: современная российская практика. Terra Economicus. 2015. Том. 13. № 3. С. 16-33.

9. Капелюшников Р. Институциональная природа переходных экономик: российский опыт современного. Кто и когда стремится вести Россию? / под. общ. ред. Т.И. Заславской. М.: МВШСЭН, 2001. 380 с.

10. Варга Н.І. Соціологічні основи дослідження неформальної економіки і зайнятості. Вісник Національного університету «Юридична академія Украйни ім. Ярослава Мудрого». Серія: Соціологічна. Х. : Право, 2016. № 3 (30). С. 108-116.

11. Капелюшников Р. И. Неформальная занятость в России: что говорят альтернативные определения? Журнал Новой экономической ассоциациии. 2013. № 4 (20). C. $52-83$.

\section{Варга Н. И. Перспективы концептуального исследования неформальной занятости}

В статье рассмотрены концептуальные перспективы исследования неформальной занятости. Дуальный характер институциональной средь приобретает выраженную специфику в условиях институциональных изменений в переходньх обществах. Формируется феномен двойной институциионализации как специфической характеристики переходного общества. В проиессе роста альтернативных институтов нарушается определенный институциональный баланс как между официальными институтами, так и между неформальньми институтами, а также между новыми официальными и старыми неформальными институтами.

Целью данной статьи является предоставление критического обзора того, как неформальная занятость была определена и измерена, вместе с отдельными выводами о ее масштабах и характере, а также краткое изложение конкурирующих взглядов относительно ее роли в современной экономике и как ее можно решить. В статье описан процесс институционализации неформальных практик, которые пронизывают каждую отдельную форму экономической реальности, - это компромисс формальных правил и сочиальных норм. То есть неформальные практики коренятся в разрыве законов и неписаных норм поведения. Показано, что чем глубже пропасть, тем слабее механизм принуждения к соблюдению закона, поскольку более распространены неформальные практики. Точно так же неформальные практики не просто укоренены в законах и социальных нормах, а, будучи массовыми, неизбежно ведут к «разрушению опор», а именно к сознательной коррекиии законов и непреднамеренному изменению сочиальных норм общества. Сами формальные правила применяются исключительно под воздействием неформальных практик. Они неразделимы. Временная, сменная или случайная занятость (занятость на основе срочных контрактов, на основе контрактов на определенный объем работы, сезонная занятость и т. д.) получила широкое распространение в нашей стране в условиях переходной экономики в качестве стратегии адаптации к изменяющимся условиям. Проведен сравнительный анализ обсуждаемых подходов. Необходимость изучения неформальной занятости, понимание этого явления и необходимость его регулирования обоснованы. 
Mыл пришли к выводу, что формальное и неформальное существуют отдельно, при этом используется термин «сектор». Но как только мьл вступаем в дискуссию о бюрократическом и небюрократическом управлении, мы замечаем преемственность формальных и неформальных заказов. В данной статье общий вектор исследований неформальной экономики смещцается со структурного на институциональное направление. Крайне важно использовать комплексный подход, который включает в себя положение и теоретические элементы различных школ. Да, неформальная и формальная экономика государства переплетаются $u$ формируют определенный социальный контекст функиионирования неформальной занятости. Доказано, что существует связь формального и неформального регулирования. Неформальная практика может: сместить формальные правила, заменив их; занимать пространство, свободное от формального регулирования; нарушать «не букву, а дух закона», используя правовой инструмент в качестве инструмента для достижения неформальных договоренностей.

Неформальная вторичная занятость позволяет в некоторой степени обеспечить мобильность и более высокий уровень занятости в этом случае, снижая риск безработииы и увеличивая шансы на трудоустройство. Это определенно соответствует интересам работников, дает возможность работать, возможность получить свои первые деньги и чувствовать себя независимым. Не следует забывать, что работник в первую очередь рассматривает нестандартную занятость при отсутствии сочиальной зашиты. К объективным недостаткам неформальной занятости работников относятся низкий уровень оплаты труда, отсутствие контроля над безопасностью рабочих мест и в большинстве случаев - отсутствие перспектив карьерного роста.

Ключевые слова: занятость, неформальная занятость, социальная доверие, эксполярная экономика.

\section{Varha $\mathbf{N}$. The conceptual prospects of research informal employment}

This article studies the major theoretical approaches in the definition of informal employment. The aim of this article is to provide a critical overview of how informality employment of has been defined and measured, together with selected findings on its extent and character, and a summary of competing views regarding its role in contemporary economies and how it can be tackled. The article describes the process of institutionalization of informal practices that penetrate every single form of economic reality - this is a compromise of formal rules and social norms. That is to say informal practices are rooted in the gap of the laws and unwritten norms of behavior. It is shown that the deeper the gap, as well as the weaker the mechanism of enforcement for obeying the law, since more abundant informal practices are. Similarly, informal practices do not just rooted in the laws and social norms, but being massive, inevitably lead to the "destruction of the supports", namely inducing the conscious correction of laws and unintentional modification of social norms of society. Formal rules themselves are solely applied under the impact of informal practices. They are inseparable. Temporary, changeable or occasional employment (employment based on fixedterm contracts on the basis of contracts for a certain amount of work, seasonal employment etc.) has become widespread in our country under the conditions of a transitional economy, as a strategy of adaptation to changing conditions. Comparative analysis of the approaches under discussion is implemented. The 
necessity of studying informal employment, understanding of this phenomenon and the necessity of its regulation are justified.

We have come to the conclusion that the Formal and Informal exist separately, while using the term "sector". But as soon as we enter into a discussion about the bureaucratic and non-bureaucratic management, then we notice the continuity of formal and informal orders. Since in the given article the general vector of studies of the informal economy is shifting from the structural to the institutional direction. It is imperative to use a comprehensive approach that incorporates the position and theoretical elements of different schools. Yes, informal and formal economies of the state intertwine and form a certain social context of the functioning of informal employment.It is proved that the relation of formal and informal regulation. has at least three grades. Informal practices may: displace the formal rules, replacing them; occupy space free of formal regulation; break "not the letter but the spirit of the law", using a legal instrument as a tool to achieve informal arrangements.

Informal, secondary employment allows to some extent to provide mobility and a higher employment rate in this case reducing the risk of unemployment and increasing the chances of employment. It is definitely corresponds to the interests of workers. It gives an opportunity of underwork, chance to get your first money and feel independent. It should not be forgotten that the employee primarily considers a nonstandard employment with the lack of social protection. The objective disadvantages of informal employment for the workers include a low level of payment, lack of control over the safety of the workplaces and in most cases - lack of career prospects.

Key words: employment, informal employment, social trust, expolar economy. 